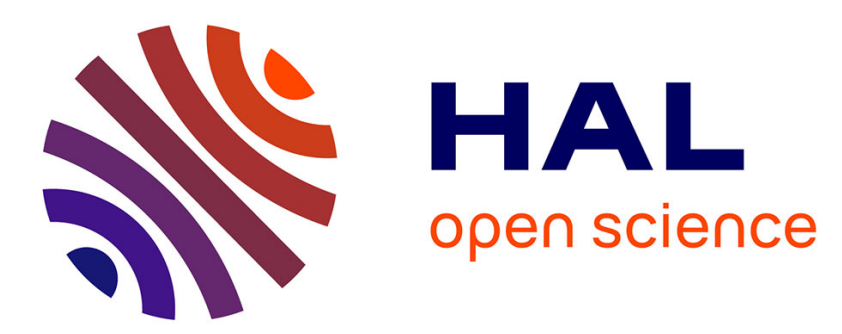

\title{
Knowledge and beliefs in economics: the case of the Austrian tradition
}

Richard Arena, Agnès Festré

\section{To cite this version:}

Richard Arena, Agnès Festré. Knowledge and beliefs in economics: the case of the Austrian tradition. R. Arena and A. Festré. Knowledge, Beliefs and Economics, Edward Elgar, pp.35-58, 2006. halshs00271351

\section{HAL Id: halshs-00271351 https://shs.hal.science/halshs-00271351}

Submitted on 8 Apr 2008

HAL is a multi-disciplinary open access archive for the deposit and dissemination of scientific research documents, whether they are published or not. The documents may come from teaching and research institutions in France or abroad, or from public or private research centers.
L'archive ouverte pluridisciplinaire HAL, est destinée au dépôt et à la diffusion de documents scientifiques de niveau recherche, publiés ou non, émanant des établissements d'enseignement et de recherche français ou étrangers, des laboratoires publics ou privés. 


\title{
3. Knowledge and beliefs in economics: the case of the Austrian tradition
}

\author{
Richard Arena and Agnès Festré
}

\subsection{INTRODUCTION}

The Austrians contributed to the analysis of the impact of individual knowledge and beliefs on economic activity more than any other School in the history of economic thought. This statement should not surprise the reader. The founding fathers of this school are strongly associated with a subjectivist conception of economics, in which cognitive capacities and the level of information of individual agents play an essential role in the explanation of their decision-making processes. They also spent a significant amount of time researching topics that are of the utmost importance to anyone interested in the role played by knowledge and beliefs in economics: Menger dedicated a lot of attention to the problem of the emergence of institutions and behavioural rules and placed great emphasis on the role played by the process of diffusion of beliefs within this context; BöhmBawerk dealt with the frontiers of pure economic theory and was interested in the impact of power and social relations on economic activity (BöhmBawerk 1914). As for Wieser, he built a real economic sociology approach and underlined the influence of organizational and social interactions in this context.

In this chapter, we shall concentrate on the second generation of Austrian economists, in particular on the contributions of von Mises, Hayek and Schumpeter who, despite developing very different approaches, shared many features of the intellectual vein of the founding fathers of the School.

At first sight, the subjectivist stance of most Austrian authors suggests that they attached importance to the role of individual beliefs in economic activity. It also suggests that these economists were reluctant to deal with social norms or collective beliefs. We will, however, show that their approaches are more complex than might appear at first sight. On the one hand, von Mises, Hayek and Schumpeter had divergent views of individual decision-making processes. On the other hand, and insofar 
as they advocated methodological individualism, they had to tackle the problem of inter-individual co-ordination. The way they solved this problem differed substantially and did not always exclude, as we shall see, a recourse to collective beliefs or social rules in their analyses. In short, our reading of the contributions of von Mises, Hayek and Schumpeter is an attempt at a more thorough analysis of the role of individual and collective beliefs in the working of markets. It also allows us to see how a strictly subjectivist approach to economic behaviour and rationality can come up against serious problems relating to inter-individual co-ordination. To mention but a few:

- how to describe the nature of the state (or states) of the economy that result from individual agents' choices through direct or indirect interactions?

- Does this state or these states imply a prior agreement on collective beliefs by individual agents?

- How should optimality issues be dealt with?

These types of questions will be guiding our reading of the three Austrian authors considered in this chapter.

\subsection{LUDWIG VON MISES: APRIORISM AND INDIVIDUAL BELIEFS}

Ludwig von Mises undoubtedly holds a special place in the second generation of the Austrian School. First, he is generally thought of as the eldest representative of this generation, since he was the first to bring about changes to the message delivered by the founding fathers of the Vienna School. Secondly, he played a fundamental role in the creation of the modern 'American' version of this School. Finally, von Mises is very often associated with the defence of radical subjectivism. This is very pertinent to our issue at hand. We shall, therefore, first examine the analytical consequences this defence implies.

\subsubsection{Decision and Human Action in von Mises}

As suggested by the title of his fundamental 1949 work, Human Action: A Treatise of Economics, von Mises starts from the notion of 'human action', which he takes as the basic unit of his analysis, and defines 'purposeful behaviour', as a 'will put into operation and transformed into an agency', the purpose of which consists in 'a person's conscious adjustment to the 
state of the universe that determines his life' (von Mises [1949] 1996, p. 11), or, to be more precise, in 'the satisfaction of the acting man's desire' (ibid., p. 14). This conception of human action from which von Mises tries to build a general theory - praxeology - derives from the Kantian philosophic tradition. In this perspective, von Mises considers that logical reasoning is the main engine of human activity (von Mises [1962] 1979, p. 44). It means, for the author, that the 'category' of human action is part of the structure of the spirit itself. To put it differently, any argumentation based on a priori true assertions and on a sequence of well-formulated logical stages leads to absolutely certain conclusions.

This constitutes the first foundation of von Mises's 'apriorist' approach. However, this methodological principle is not sufficient to characterize his approach. On the one hand, according to von Mises, every economic and social fact can be reduced to a theoretical statement. On the other hand, these statements can not be 'tested' empirically or be the subject of confirmation or falsification procedures. The only two criteria of truth accepted by the author are the internal logical coherence of a statement and its applicability in given historical situations. This apriorist conception therefore implies the refusal of an analysis of beliefs and human behaviour which would privilege their content or their empirical meaning. Praxeology concerns human action, 'irrespective of all environmental, accidental, and individual circumstances of the concrete acts. Its cognition is purely formal and general without reference to the particular features of the actual case' (ibid., p. 32). It also deals with the 'ultimate category' constituted by 'the logical structure of human mind' (Ibid. p. 34). It is in this sense that von Mises notes that the 'fundamental logical relations are the indispensable prerequisite of perception, apperception and experience'. (ibid., p. 34).

However, von Mises's apriorism does not exclude subjectivism. Indeed, he writes:

[N]obody is in a position to substitute his own value judgments for those of the acting individual, it is vain to pass judgment on other people's aims and volitions. (ibid., p. 19).

This subjectivism does not, however, adapt to unconscious determinants of the decision process. Von Mises, as already emphasized, conceives of human action as deliberate behaviour or conscious adaptation.

\subsubsection{Human Action and Individual Beliefs}

Von Mises's subjectivism implies the existence of individual beliefs exclusive to every agent. He thus encounters the problem of co-ordination between 
autonomous decisions and actions of actors (von Mises [1949] 1996, p. 55). This problem is all the more crucial as, for our author:

society is nothing but the combination of individuals for cooperative effort. It exists nowhere else than in the actions of individual men. It is a delusion to search for it outside the actions of individuals. To speak of a society's autonomous and independent existence is a metaphor which can easily lead to crass errors. (Ibid., p. 143)

Von Mises's apriorism, however, moderates his subjectivist individualism. In fact, two principles govern the logical structure that is common to everyone: the principle of causality and the principle of teleology (ibid., p. 25). These two principles play an essential role in von Mises's analysis of the co-ordination of individual beliefs.

\subsubsection{From Individual Beliefs to Inter-individual Co-ordination}

In order to solve the problem of the compatibility between the subjectivist approach to individual beliefs and market co-ordination, von Mises starts from the idea of introspection:

it is beyond doubt that the principle according to which an Ego deals with every human being as if the other were a thinking and acting being like himself has evidenced its usefulness both in mundane life and in scientific research. It cannot be denied that it works. (Ibid., p. 24, cf. also von Mises ([1962] 1979, p. 72)

This idea is simple. Given that, for von Mises 'it is impossible for the human mind to conceive a mode of action whose categories would differ from the categories which determine our own actions (von Mises [1949] 1996, p.29), agents, by introspection, can redraw the logical principles governing the ways of thinking of their allies or competitors. This is obviously only possible because it is assumed that every agent is endowed a priori with the same reasoning capacities. These are capacities 'common to all man' (ibid., p. 35).

In this context, introspection is only meaningful if it is combined with 'observation'. In fact, although the logical categories of causality and teleology are given a priori, this is not the case for the scale of values or wants of the agents. In von Mises's terms, this 'manifests itself only in the reality of action', by means of observed behaviour (ibid., p. 95).

In other words, von Mises, in line with his constant preoccupation to carefully separate the field of psychology from the one of economic analysis, rejects the possibility of interpreting this behaviour psychologically.

So, if agents can communicate by going beyond their strictly subjective universes, this is neither because they share the same cognitive capacities 
(in the sense of the Hayekian possibilities of appropriation of the reality by the brain), nor because they have similar psychological profiles. It is because their spirit reveals the same logical structure.

This logical structure leads agents to analyze real phenomena, albeit imperfectly, by using similar schemes, such as those implied by the principles of teleology and causality. However, the agents' knowledge is inevitably imperfect. In fact, agent behaviour is not governed by strictly deterministic laws. Besides, the principles of teleology and causality are not sufficient to allow instant foresight of the future or the behaviour of other individuals. Thus, experience and observation enter the scene. Causality is revealed to agents only through the search for the "regularity and the "law"' of observed phenomena (ibid. p. 22).

The apriorist hypothesis of the universality of the logical categories which characterize the common structure of human minds thus constitutes, for von Mises, the necessary condition for the communication of beliefs between agents and for the understanding of individual expectations. If this condition is necessary, it is however far from sufficient.

\subsubsection{The Processes of Division of Individual Beliefs}

Although von Mises champions radical subjectivist individualism, he does not endorse the contractualist explanation of the transition from the Natural State, where man was isolated, to the Social State, where man enters into connection with other people. For von Mises it is inconceivable to suppose that man can live 'in abstracto' (von Mises [1949] 1996, p. 46). Man is always located within a socio-cultural context, which influences his subjective choices. Far from being unimportant, this influence can be determining for certain agents.

All 'common men' do is adapt the ideas and beliefs they inherit from the past andlor from their environment. From this point of view, the description von Mises provides is striking - the common man:

does not himself create his ideas; he borrows them from other people. His ideology is what his environment enjoins upon him [...] Common man does not speculate about the great problems. With regard to them, he relies upon other people's authority, he behaves as 'every decent fellow must behave', he is like a sheep in the herd. (Ibid., p. 46)

These 'common men' are to be distinguished from those that von Mises calls the 'promoters'. They are seen as 'pacemakers', 'who have more initiative, more venturesomeness, and a quicker eye than the crowd' (ibid., p. 255). The promoter is, above all, a pioneer and this is why von Mises also calls him the 'creative genius' (ibid., p. 139). His incentive 'is not the desire to bring 
about a result, but the act of producing it' (ibid., p. 139). The promoters correspond to 'a general characteristic of human nature' (ibid., p. 269) and that is why, as in Schumpeter, they exist in most societies, at different times or in different activities (ibid., pp. 255). In the context of market economies, these promoters appear predominantly, according to von Mises, as entrepreneurs.

The distinction between 'promoters' or 'creators' and 'ordinary men' is important. First, it is a feature of the Austrian economic tradition inherited from Menger and Wieser (Arena and Gloria-Palermo 2001). Secondly, it allows us, according to von Mises, to explain the sharing, or rather the diffusion, of new individual beliefs via a social process of imitation. So, common men follow 'habits' or routines, which they modify only if they are convinced that the promoters will improve their well-being (von Mises [1949] 1996, p. 47). In this sense, the individual beliefs of common men are indeed shared individual beliefs; but, for von Mises, they can never be autonomous collective beliefs of individuals, as in Durkheim, for example (ibid., pp. 42-3).

The radical anti-holism of von Mises allows us to understand why his conception of the diffusion or the sharing of individual beliefs is related to imitation: if several agents agree to adopt the specific beliefs of a particular individual, it does not mean that they stop exercising individual choices:

They can either all act together in accord, or one of them may act for them all. In the latter case the consideration of the others consists in their bringing about the situation which makes one man's action effective for them too. (Ibid., 44).

This approach, in terms of shared individual beliefs, appears coherent. Von Mises makes use of it in order to analyze the functioning of the market. The latter is not 'a place', 'a thing', or a 'collective entity' (ibid., p. 257), it is a 'process' in which 'value judgments' are compatible with individual beliefs (ibid.). Promoters-entrepreneurs play a leading role in this framework because they 'take the lead': they are 'the shrewder individuals [who] appreciate conditions more correctly than the less intelligent and therefore succeed better in their actions.' (ibid., p. 328). Their attentiveness and speculative behaviour focussed on the discovery of new opportunities are critical (ibid., p. 329), especially since, in the long run, they can only submit themselves to the 'sovereignty of the consumers'. (ibid., p. 269).

Despite his views on the functioning of the market, von Mises did not go on to an operational analysis. If one can credit the author for a stimulating approach to the role of the promoters-entrepreneurs, his ideas on the ways markets are organized did not lead to a theory of auctions. Although von Mises suggests that prices convey efficient signals that lead to equilibrium 
between production and exchange, he fails to explain how entrepreneurial activity leads to prices and why they 'tell the producers what to produce, how to produce and in what quantity' (ibid., p. 258). The omnipotence and the equilibrating character of the market are not proved rigorously and, unfortunately, von Mises' radical condemnation of the use of mathematics in economics cannot reassure the reader about this point (see, for instance, ibid., pp. 350-58). Moreover, it should be pointed out that von Mises' analysis of the process of diffusion of individual beliefs is not restricted to the role of the promoters since, in the last resort, the 'sovereignty of consumers' constitutes the prime mover of the market process (ibid. p. 269).

Another factor explaining the sharing of individual beliefs is the "catallactic function of money'. Von Mises explicitly draws a parallel between money and the promoter, noting that 'the notion of money [similarly to the notion of the entrepreneur-promoter] also defies a rigid praxeological definition' (ibid., p. 255).

First of all, a currency is not an a priori medium of exchange but a 'tool of action' because 'prices in currency are the only vehicle of economic calculation' (ibid., p. 201) and 'monetary calculation is the guiding star of action' (ibid., p. 210).

Moreover, monetary prices allow the comparison between alternative uses of resources over time, i.e., intertemporal calculation. The key-function of money is to provide individuals with a scale against which to assess the future consequences of their present actions. Money thus allows the introduction of the dimension of evaluation prior to human action, namely, the appreciation or anticipation by individuals of alternative ways of removing the uneasiness they feel (ibid., p. 224).

Secondly, money gives rise to an objective dimension through the notion of purchasing power. This is passed on to individuals and serves as a guide for action. According to von Mises, this does not mean that monetary calculation can be used for 'any consideration which does not look at things from the point of view of individuals' such as, for instance, the statistical forecast of aggregate economic magnitudes or the calculation of collective projects (ibid., p. 230). On the other hand, the specific function of money as a generalized medium of exchange confers it an objective dimension.

Von Mises first indicates that money is to be distinguished from other economic goods in the sense that its subjective value depends on an objective economic characteristic: its purchasing power. Contrary to the value of any other economic good, the purchasing power of money cannot be influenced by non-economic factors such as technology or the psychology of individuals (von Mises [1924] 1981, p. 118). Consequently, it is not necessary to base the 
purchasing power of money on the existence of a demand for money as an instrument of exchange or for its use for industrial purposes:

That component of money's purchasing power which is an outcome of the services it renders as a medium of exchange is entirely explained by reference to these specific monetary services and the demand they create. (von Mises [1949] 1996, p. 409, our emphasis)

This passage illustrates the self-referential and conventional character of currency. In particular, the self-referential nature of money becomes clear when we consider that money would cease to exist were individuals to lose memory of purchasing power:

It is the fact that radically distinguishes the determination of the purchasing power of money from the determination of the mutual exchange rates between the various vendible goods and services. ... Knowledge about past prices is for the buyer merely a means to reap a consumer's surplus. If he were not intent upon this goal, he could, if need be, arrange his purchases without any familiarity with the market prices of the immediate past, which are popularly called present prices. He could make value judgments without appraisal. ... But if knowledge about money's purchasing power were to fade away, the process of development indirect exchange and media of exchange would have to start anew. (Ibid., p.411, our emphasis)

Although the analysis of the role of money proposed by von Mises is worth considering, it does not provide a rigorous analysis of the formation of the monetary prices of commodities. All we can say is that it is left as a possible line of research.

On the whole, von Mises's approach does not provide a satisfactory analysis of the impact of individual beliefs and shared individual beliefs on the functioning of a market economy. However, it highlights some of the difficulties confronting a strictly subjectivist approach to beliefs.

\subsection{FRIEDRICH VON HAYEK: INDIVIDUAL BELIEFS AND KNOWLEDGE OF THE SOCIETY}

Among the important economists of the twentieth century, Hayek is undisputedly the one who contributed the most to the analysis of the role of knowledge in economic activity. The scope of his epistemological thought remains unmatched in this field. No wonder, therefore, that Hayek belongs to the group of Austrian economists who tried to connect individual beliefs, social knowledge and the functioning of market economies. In order to 
better justify Hayeks' presence in this section, we must first turn to his conception of knowledge.

\subsubsection{Hayek's Conception of Knowledge}

One can find Hayek's best definition of knowledge in his 1960 work entitled The Constitution of Liberty:

The growth of knowledge and the growth of civilization are the same only if we interpret knowledge to include all human adaptations to environment in which past experience has been incorporated. Not all knowledge in this sense is part of our intellect, nor is our intellect the whole of our knowledge. Our habits and skills, our emotional attitudes, our tools, and our institutions - all are in this sense adaptations to past experience which have grown up by selective elimination of less suitable contact. They are as much an indispensable foundation of successful actions as is our conscious knowledge (Hayek [1960], p. 26)

This passage provides a good illustration of the reasons that lead Hayek to believe that individual knowledge involves more than simply 'explicit and conscious knowledge' (ibid., p. 25). Fleetwood (1997, pp. 164-6) compellingly argues that Hayek's broad conception of knowledge includes three main forms of knowledge: general explicit knowledge, local explicit knowledge (ibid., p. 165) and tacit and unconscious knowledge. This last form of knowledge is essential to Hayek's analysis. It also illustrates a fundamental difference between Hayek and the approach adopted by von Mises. While von Mises's apriorism led him to consider exclusively conscious individual forms of beliefs and knowledge, Hayek's methodological choice paves the way for a broader conception of knowledge.

In fact, tacit knowledge refers to a form of knowledge that is accessible directly: unlike local and general explicit forms of knowledge, it does not require the preliminary definition of an objective to be deliberately learnt. It is fully 'absorbed', day after day, through the social interaction common to every individual from early childhood. It is not assimilated through formal institutions but instead by the repeated resort to rules of social conduct, the role or even meaning of which is not necessarily understood. The originality of Hayek's conception of tacit knowledge lies in its extensibility. More precisely, the behavioural rules that underlie tacit knowledge in Hayek's approach are not limited to practical and basic forms of behaviour. They can also relate to elaborate cultural traditions or professional routines.

More generally, Hayek's conception of knowledge must be understood in relation to his subjectivist methodology, which essentially rests on two justifications. 
The first, which is cognitive, is found in The Sensory Order (1952). In this book, Hayek champions the idea that the brain functions in a connectionist way, so that the point of departure of mental representations is not the physical order of things, as 'scientistic objectivism', to use Hayek's expression (cf. Hayek (1952a) chapter V), would have it, "but the product of abstractions which the mind must possess in order to be capable of experiencing that richness of the particular [of the reality]' (Hayek 1978, p. 44). The conscious experiences that individuals regard as relatively concrete and primary and which they attribute to the intrinsic properties of the physical order 'are the product of a superimposition of many 'classifications' of the events perceived according to their significance in many respects' (ibid., p. 36). There are thus as many subjective forms of knowledge as there are individual 'nervous systems', i.e., as there are heterogeneous agents.

The second justification for Hayekian subjectivism is found in what Hayek calls the 'social division of knowledge'. For Hayek, as a civilization develops, the knowledge of its society becomes more complex and specialist. However, no individual agent can have access, to such knowledge alone. This is dispersed within society and each of the individuals constituting it can have access only to a very small part of the social knowledge and, in particular, to the processes by which social and economic activity is regulated and reproduced globally.

It is against the background of these two justifications that we are to understand the very wide conception of knowledge Hayek developed. In this perspective, the existence of tacit knowledge does not constitute a phenomenon to be analyzed in itself. Instead, it represents one of the essential forms of dispersed knowledge, which is difficult to disseminate in society and which Hayek endeavours to characterize.

\subsubsection{Knowledge and Individual Beliefs}

Hayek's subjectivist methodological choice leads him to investigate the features of a 'cognitive' individual rationality, to use the distinction between cognitive and instrumental rationalities used by Boudon in this volume. The cognitive capacities that individual agents must mobilize refer to their own 'mental map'. What Hayek calls the 'map' is 'the semi-permanent apparatus of classification', which 'provides the different generic elements from which the models of particular situations are built'. (Hayek, 1952b, p. 89).

In fact, the idea of a mental map conveys the cognitive limits of the mental considerations of individuals. Rather than 'a sort of schematic picture of the environment' it supplies 'a sort of inventory of the kinds of things of which the world is built up, a theory of how the world works' (ibid., p. 89). For Hayek, this approach does not conflict with some of the 
tools commonly used in microeconomics, what he calls the formal 'logic of the choice'. However, he thinks they require adaptation. So, during the debate on 'socialist calculation', Hayek underlines the fundamentally subjective representation according to which agents interpret the 'data' or 'fundamentals' of the general economic equilibrium scheme, such as the qualities of consumer goods or the description and implementation of the available techniques of production (Hayek 1935).

Therefore, the economic behaviour of each individual agent is embedded in the framework of his own theory of how the world works. It means that each individual makes decisions according to his own set of 'structural' individual beliefs, to use Walliser's terminology in this volume. These structural beliefs shape what we could call 'circumstantial' beliefs, namely, beliefs which govern specific decisions related to particular circumstances and to particular expected economic results at a given point of time.

These decisions give rise to actions which, in their turn, produce results which the agent compares to his own expectations. The divergence perceived by the individual between his expectations and the actual outcomes of his actions leads him to revise his circumstantial and sometimes, albeit less frequently, his structural beliefs. This revision process is stronger when the observation of actual results convinces the agent of the 'errors' in his 'attempt' and provides him with the opportunity to eliminate certain beliefs. If, on the other hand, the 'attempt' is successful, a true selection of beliefs takes place. Indeed, in the long run, as pointed out by Garrouste (1999, p. 891), structural beliefs become stronger and are gradually transformed into individual abstract rules, comparable to genuine routines. In fact, the agent becomes aware that his structural beliefs help him obtain results that are superior to the other possible beliefs.

However, despite the fact that individual beliefs are subjective, they are not independent from those of the other agents.

\subsubsection{Individual Beliefs and Social Rules}

If economic agents were only to follow their beliefs and individual routines, it would be difficult to understand how even a minimal social order could result from a multitude of unco-ordinated economic actions. Hayek is clearly aware of this problem which, he believes, arises out of the need to distinguish 'social phenomena' or group actions from 'individual actions' (Hayek 1948 p. 48). This problem turns out to be particularly complex for two main reasons.

First of all, co-ordination of individual behaviours is contextual. This observation is not surprising in a Hayekian context: here 'fundamentals' are allowed to vary continuously and, moreover, it is impossible to grasp them 
objectively, even at a given point in time (Arena 1999, p. 851). Referring to the context thus implies that the same set of individual rules of conduct can lead to very different social orders, if the context is associated with different 'circumstances of time and place'.

Secondly, there is some divergence between the strictly individual motives of agents and the criteria allowing the ranking of preferences in favour of one social order instead of another: Hayek actually notes 'that there is no other way toward an understanding of social phenomena but through our understanding of individual actions directed toward the people and guided by their expected behavior'. (Hayek 1948, p. 6). Moreover, 'the reason for this is simply that $[\ldots]$ wholes or social structures are never given to us as natural units, are not definite objects given to observation, that we never deal with the whole of reality but always only with a selection made with the help of our models' (ibid., p. 74).

In this context, it seems that there is a significant gap between the rules that govern the pursuit of individual self-interest and those allowing the emergence of a social order: 'knowledge of society' cannot be reduced to the sum of individual beliefs. As shown by Vanberg (1986), this is a serious problem in Hayek because he is unable to provide a convincing framework ensuring the compatibility between his subjectivist approach to the spontaneous order and his later theory of 'cultural evolution'. However, a first answer can be sketched out based on his writings.

In considering Hayek's cognitive approach, Birner (1999, pp.67-8) underlines the analogy, developed by Hayek himself, between the organization of the human brain and that of society. This marks the limits of Hayekian subjectivism, because 'knowledge and beliefs of different people' are not completely diverse but 'possess a common structure which makes communication possible' (Hayek 1952b, p. 49). In this perspective:

individuals which compose society are guided in their actions by a classification of things or events according to a system of sense qualities and of concepts which has a common structure and which we know because we, too, are men. [...]. Not only men's action toward external objects but also all the relations between men and all the social institutions can be understood only by what men think about them. Society as we know it is, as it were, built up from the concepts and ideas held by the people, and social phenomena can be recognized by us and have meaning to us only as they are reflected in the minds of men. (Hayek 1952a, pp. 57-8, our emphasis)

This therefore implies that the rules of conduct which guide the behaviour of agents are clearly dependent on the mental 'common structure' of men. Thus it is easy to understand why Hayek admits that individuals belonging to the same historic and/or socio-cultural environment tend to share common 
individual beliefs. This viewpoint is obviously reinforced by the importance Hayek attributes to the relation between innovative and imitative individual decisions in the process of emergence of behavioural regularities.

Vanberg (1986) notes that this approach is still unsatisfactory: if the selforganization of the agents is the emanation of individual choices, it does not however lead inevitably to a socially optimal state. Hayek postulates the social superiority of the market order without demonstrating it in a convincing way, when he refers to the notion of 'empirical tendency toward equilibrium', or to a notion close to Pareto's optimum or even to the idea that there exists a dominant social group (cf. Arena 2003). If one wants to abandon this type of petitio principii, one should go back to the notion of social order and its foundations in a Hayekian perspective. However, before we examine them, it is necessary, first, to pay attention to the concept of social rule in Hayek.

\subsubsection{Social Rules and Collective Beliefs}

Up until this point, we used the word 'beliefs' in the sense of 'individual beliefs'. We saw at first how these beliefs could give rise to a self-reinforcement process and thus lead to the emergence of real individual rules of conduct. We then underlined how agents could converge towards shared individual beliefs, through social communication and imitation. One could thus infer from these two observations that, in Hayek, the social rules of conduct that explain the regularity and co-ordination of individual behaviour may, in turn, be defined as shared individual rules. In fact, the situation is more complex.

As some commentators have noted (Ioannides 1999, pp. 874-6; Garrouste 1999, pp. 887-91), the features of social rules of conduct that in Hayek underline the formation of a spontaneous social order similar to the one found in market societies, are threefold. First, they must be tacit, that is, 'supra-conscious', to use Hayek's expression. To put it another way, individuals follow rules of conduct, without knowing explicitly that they are doing so. Secondly, these rules must be abstract. Thirdly, tacit and abstract rules must necessarily be general. This means that they must be valid for all individuals and apply to an infinite number of particular cases. To put it another way, the content of these rules is independent from the particular individuals who adopt them or from the particular types of actions in which they are put into practice. This does not mean that their ultimate origin is not linked to the individual beliefs of agents. Simply, these rules are the result of a process of adaptation which tends to gradually erase its origin (Hayek 1960, p. 27). 
With the passing of time and the repeated use of individual rules of conduct, their tendency to become more and more abstract and general creates the conditions of their growing autonomy vis-à-vis the individuals who have implemented and/or adopted them. In the long run, these forms of conduct "consist of what we call "traditions" and "institutions", which we use because they are available to us as a product of cumulative growth without either having been designed by any one mind'. (Ibid., p. 27).

This interpretation is confirmed by Hayek's analysis of the 'properties' that social rules are supposed to possess in order to produce a global order that appears to be independent from individual actions. These 'properties' explain how individual rules (even shared rules) can be transformed into social rules, i.e. 'normative' rules which 'tell' individuals what they can or cannot do. As we already noted, the social process of standardization of rules first results from similarities between individual mental processes. Its origin can also be found in the existence of a 'common cultural tradition'. Finally, it can be enforced by, say, the State or the law, and imply sanctions in case of violation. The above remarks confirm that social facts or norms have gradually acquired such a large autonomy with respect to individuals, that they appear to them as strictly exogenous (customs, convention, culture, law, etc.). This is why they appear to be the real causes of the process of social standardization of individual rules. Therefore, if shared individual beliefs often imply true social beliefs, it is mainly because individuals usually choose their individual rules of conduct within the repertoire of the available social rules.

It then remains to understand how the mechanism of selection between rules and available social beliefs works. This mechanism is essential since it allows us to understand the emergence of rules or optimal social beliefs. The answer Hayek puts forward corresponds to his theory of cultural evolution:

All that we can know is that the ultimate decision about what is good or bad will be made not by individual human wisdom but by the decline of the groups that have adhered to the 'wrong' beliefs. (Hayek 1960, p. 36)

However, one can still wonder how the process of selection of social rules leads to a situation of relative autonomy with respect to individual knowledge beliefs, even if Hayek strongly advocates subjectivist individualism. This autonomy is taken into account by Hayek through his reference to the 'knowledge of society' (ibid., p. 25).

Individuals have no direct access to this kind of knowledge (ibid. p. 25). On the other hand, for Hayek, the simultaneous recourse, by individuals, to their own particular knowledge leads each of them to benefit from what 
one could call positive externalities stemming from social interaction. All that remains then is to understand how individuals can benefit indirectly from this knowledge.

Hayek's answer is obvious: tradition provides agents with a set of rules that are superior or 'wiser' than human reason (Hayek 1988, p. 73). Fleetwood elaborates on this answer, noting that: 'by drawing upon these rules as surrogates, then, agents avail themselves of the collective wisdom of an evolving society, and are thereby enabled to initiate socioeconomic activity, although they can never know or articulate this collective wisdom.' (Fleetwood 1997, p. 170).

To sum up, Hayek actually allows for the existence of a 'knowledge of society', or 'of the impersonal process of society', which differs from the mere juxtaposition of individual kinds of knowledge (Hayek 1960, p. 65). This means that, for Hayek, we must distinguish between two analytical levels (see for instance, ibid., p. 28). The first is entirely governed by the methodology of subjectivist individualism and, therefore, only refers to individual beliefs, be they shared or not. The second corresponds to a kind of knowledge that individuals cannot access directly. It is the outcome of the interactive effects of their actions. In order for this impersonal knowledge to be as efficient as possible, it is first necessary that a social process of selection generate rules allowing men to live together in an open society, in other words, in a type of social order that permits individuals to make free but compatible decisions. It is also necessary that these selected rules produce the largest and best 'knowledge of society'.

It is on this last point that Hayek's failure is self-evident: the author fails to provide a satisfactory explanation of the social effects of individual beliefs on the working of market economies. Like von Mises, Hayek takes the tendency of the market to move towards equilibrium for granted without proving it rigorously. His solution is, however, more elaborate - essentially because of its ability to take into account the tacit as well as the unconscious aspects of individual knowledge. Moreover, through the introduction of the analytical device of the 'knowledge of society', it entails an evolutionary dimension which did not exist in von Mises. This level of knowledge turns out to be essential for Hayek's intellectual construct, but its relative autonomy does not question the individualistic and subjectivist methodology of the author since no individual is capable of appropriating it directly. Finally, if one is willing to place Hayek's treatment of knowledge into a framework based on self-organization and if one gives up the postulate of a determinist and systematic tendency of the economy towards a unique and stable equilibrium, Hayek's solution seems more promising than the one put forward by von Mises. 


\subsection{JOSEPH SCHUMPETER: THE SOCIAL FOUNDATIONS OF INDIVIDUAL BELIEFS}

At first sight, it might seem surprising that we chose to include Schumpeter's contribution in this chapter. Although Schumpeter was born within the Austro-Hungarian Empire, he is not usually considered as a member of the so-called Austrian School. However, this hesitation does not stand up to scrutiny. Schumpeter was strongly influenced by the first generation of the School in particular, by von Wieser (Arena and Gloria-Palermo 2001). Moreover, he dedicated a great number of contributions to the study of rationality and individual beliefs (see above all Schumpeter [1940] 1991), a point that is often neglected in the literature. This is why we believe that his contribution deserves particular attention.

\subsubsection{The Schumpeterian Analysis of the Foundations of Beliefs and Individual Motives}

According to Donzelli (1983, p. 639), Schumpeter was the first to introduce the expression 'methodological individualism'. In fact, an entire chapter of his 1908 work entitled Das Wesen und der Hauptinhalt der theoretischen Nationalökonomie is dedicated to providing a precise definition and to a detailed discussion of methodological individualism and its main alternative: methodological holism. The approach privileged by Schumpeter does not consist in establishing the superiority of one of these two methods over the other but in specifying their respective domains of relevance.

One of the fundamental purposes of the author in this context is to estimate the impact of the existence of social classes or groups on the functioning of society. In his 1927 essay on the Social Classes ('Social classes in an ethically homogenous environment'), Schumpeter writes the following in referring to the Marxian analysis of investment:

Manifestly, the captures surplus value does not invest itself but must be invested. This means on the one hand that it must not be consumed by the capitalist, and on the other hand that the important point is how it is invested. Both factors lead away from the idea of objective automatism to the field of behavior and motive - in other words, from the social 'force' to the individual-physical or family; from the objective to the subjective. [...] But the crucial factor is that the social logic or objective situation does not unequivocally determine how much profit shall be invested, and how it shall be invested, unless individual disposition is taken into account. Yet when that is done, the logic is no longer inherent solely in the system as distinct from the individuality of the industrialist himself. (Schumpeter [1927] 1951, p. 155). 
For Schumpeter, the task of the social scientist is, therefore, to study individual specificities as well as their context embedded in the reality of social structures.

Schumpeter's reference to these structures, and, in particular, to the division of society into social classes does not impair the methodological individualism of the author. For Schumpeter:

\footnotetext{
The ultimate foundation on which the class phenomenon rests consists of individual differences in aptitude. What is meant is not differences in an absolute sense, but differences in aptitude with respect to those functions which the environment makes 'socially necessary' - in our sense - at any given time. (ibid., p. 210)
}

Thus, for Schumpeter, the degree of self-interest and class interest for agents varies according to the social context. If one considers, for example, 'traditional' societies, interest for the group and holism prevail. If, on the other hand, one is interested in market economies, which is the case for part of the field of pure economics, the individualistic approach becomes essential.

These developments are radically different from the approaches of both von Mises and Hayek, whose explicit purpose was to explain the functioning of markets in an individualistic and subjectivist way. For his part, Schumpeter combines, in an eclectic way, the methods of individualism and holism, and examines the problems of rules and agent beliefs within this framework. This is also the key to reading Schumpeter's remark which states that 'it is society that shapes the particular desires we observe [... and] the field of individual choice is always, though in very different ways and to very different degrees, fenced in by social habits or conventions and the like' (Schumpeter 1934, p. 91).

This position is obviously unusual within the Austrian tradition, which is not favourably disposed towards methodological holism a priori. Indeed, in complete contradiction with Hayek and von Mises, Schumpeter does not hesitate to underline that social classes are not 'our making' or a 'creation of the researcher' but 'social entities that we observe', or 'social organisms, living, acting and suffering as such' (Schumpeter [1927] 1951, p. 137).

\subsubsection{From Motives to Routines}

Following Hayek, and unlike von Mises, Schumpeter accepts the possibility of beliefs or unconscious motives for agents. These can be of two types.

First, agents who are present in market economies have substantial but unconscious traces of collective beliefs inherited from the past and accepted 
within certain social groups. Modern economic rationality is not, for Schumpeter, a natural given fact but a slow and progressive construction.

So, the behaviour of agents is the result of motives, beliefs and composite determinants which well illustrate the mixture of holism and individualism advanced by Schumpeter. Agent behaviour indeed results from the combination of a rational motive based on the pursuit of selfinterest and from collective beliefs unconsciously inherited from the past. From this angle, economic rationality itself is not a natural characteristic of agents but rather a kind of collective belief in the need to apply three principles to a growing segment 'of the sector of social life' (Schumpeter, 1942, p. 122):

First, by trying to make the best of a given situation more or less - never wholly - according to their own lights; second, by doing so according to those rules of consistency which we call logic; and third, by doing so on assumptions which satisfy two conditions: that their number be a minimum and that everyone of them be amenable to expression in terms of potential experience' the utility of the economic calculation based on optimization; the acceptance of the 'rules' of usual logic; the use of simple hypotheses based on experience. (Ibid)

There are also other unconscious motives in Schumpeterian agents. They concern the weight of the past and the experiences to which it has given rise. These experiences are linked to the personal trajectory of an agent and they influence him unconsciously by limiting the scope of the possible behaviours he is able to conceive of. So, if the agent does not see any reason to change his activity, he will adopt a behaviour based on a mere extrapolation from circumstances that have occurred in the past. This explains the existence of real routines that contribute to create what the individual considers to be 'normality' (Schumpeter, 1939, p. 4). Reference to this normality allows the agent to formulate a structural belief, what Schumpeter calls a 'full idea of that logic which is inherent in economic things and which it is the task of scientific economics to formulate somewhat more rigorously' (ibid., p. 5). The kind of experience described above also affects the idea an agent forms about the situation of the environment through observation. We are hinting at 'the rules by which [the agent] form[s] his judgment about existing business situations' (ibid).

It is this 'situation' that implies that 'all knowledge and habit once acquired becomes as firmly rooted in ourselves as a railway embankment in the earth' (Schumpeter 1934, p. 84). Schumpeter here evokes the existence of real rules of conduct inherited from an agent's personal trajectory as well as from autonomous social factors, which sink into the 'strata of [his] subconsciousness' (ibid.). 


\subsubsection{The Weight of the Diffusion of Beliefs}

In compliance with his Wieserian conception of economic sociology, and in line with an Austrian characteristic already identified in von Mises and Hayek, Schumpeter considers that, whatever the social environment that is considered, people always divide into two groups: leaders and imitators. Schumpeter does not consider the former as superior beings or 'great men' (Schumpeter [1927] 1951, p. 216). They do not possess specific intellectual qualities which would lead them to play a pre-eminent role of a particular kind. However, they do have to exercise the both individual and social function of leadership, which is 'to command, to prevail, to advance' (ibid., p. 217).

The motives of the leaders are linked to their 'instinctive urge to domination' (Schumpeter [1919] 1951, p. 15), or to their 'excess of energy' (ibid., p. 34). These 'urges' - or Trieb (ibid., p. 83) - express the fact that the motives of the leaders are more connected to their 'instinct', a fact that explains their creativity and entails permanent changes in the sphere to which they belong. The imitators are characterized essentially by a behaviour based on the pursuit of habits as described in the previous section. They generally adopt a passive role and contribute by diffusing the beliefs, rules or innovations of the leaders. They can help reinforce these beliefs or rules and improve their dissemination in society as whole, by adopting imitative behaviour or by demonstrating their confidence in the decisions of the leaders. They can also resist them, by postponing the processes of diffusion or sometimes by preventing their mechanisms from working altogether.

The phenomenon of 'leadership' is not independent from the social context within which it appears. Thus, when referring to warlike civilizations, Schumpeter insists on the fact that leadership results from the excess energy of individuals but also contributes to the social reproduction of the group to which they belong.

The social phenomenon of leadership also contributes to the explanation of institutional change. Indeed, unlike the imitators, the leaders do not agree, partly unconsciously, to conform to the dominant rules and to minimize their efforts in order to reach a given objective. On the contrary, they adopt a conscious behaviour of innovation and, from individual beliefs of a new type, they invent new rules intended to attain new objectives. This invention - or more exactly, this innovation - requires the production of an effort. Leaders can make this effort because they have an excess of energy that is obviously useless when individual behaviour relies on routines and appears in a purely 'hedonistic' form.

The success of an economic or social innovation does not, however, depend on its intrinsic characteristics but on its acceptance by the community of the 
imitators. Imitators can show resistance to change an inclination towards routine behaviour. Schumpeter analyzes the reasons for this. One of these is particularly interesting in this context because it concerns the existence of a conflict between two forms of beliefs: those based on routine lead us to view changes as destabilizing factors, affecting established interests and increasing potential uncertainty; the others, on the contrary, lead us to see innovation as a factor of economic or social progress (Schumpeter 1939, p. 100).

One thus recognizes, in Schumpeter, a process of diffusion and sharing of beliefs similar to those found in von Mises and Hayek in many respects. One notes, however, that Schumpeter attaches specific importance to history and economic sociology in the analysis of this process.

\subsubsection{The Weight of Class Interest}

When considering social classes as 'social entities', Schumpeter is quite naturally led to analyze the concept of class interest, which seems holist a priori. Schumpeter defines social classes as 'social entities which we observe but which are not our making' (Schumpeter [1927] 1951, p. 137). In this way, social classes can be considered as distinctive 'living, acting, and suffering' entities that must be 'understood as such' (Ibid.). More exactly, for our author, a social class is a group of individuals who are capable, within a specific social context, of exercising a given social function.

This is why Schumpeter does not think that it is possible to define social classes on either a purely holistic or a purely individualistic basis:

We cannot help those who are unable to see that the individual is a social fact, the psychological an objective fact, who cannot give up toying with the empty contrasts of the individual vs. the social, the subjective $v s$. the objective. (ibid., p. 211).

This characteristic of social classes explains why class interest may exist as such and why belonging to a social class influences an individual; his behaviour, in fact, does not only depend on his own will but also on what Wieser called the 'forces of compulsion' (Wieser 1927, p. 155). It would be inaccurate to attribute to Schumpeter a definition that would make of the social class the outcome of shared beliefs among its members. Schumpeter is extremely clear on this point:

Class is something more than an aggregation of class members. It is something else, and this something cannot be recognized in the behavior of the individual class member. A class is aware of its identity as a whole, sublimates itself as such, 
has its own peculiar life and characteristic 'spirit'. (Schumpeter 1951 [1927], p. 140).

Therefore, according to Schumpeter, a social class is an autonomous entity which gives rise to collective beliefs (and not the other way around). That is why Schumpeter does not hesitate to refer to 'class interest' and to suggest a convergence of the vision of the world among members of a social class (ibid., p. 140). The class interest ever-present in all members of this class thus constitutes an autonomous social determinant 'originally quite independent of [their] will' (ibid., p. 143).

To summarize, the conception of beliefs developed by Schumpeter differs sharply from the ones of von Mises and Hayek. On the one hand, Schumpeter puts forward the idea that any economic action entails individual motives as well as autonomous social determinants. This clearly makes him stand apart from the subjectivist individualism of Hayek and von Mises. On the other hand, Schumpeter admits the existence of collective beliefs peculiar to each social class; this constitutes a further divergence from Hayek and von Mises since none of them, while sticking to the notion of shared individual beliefs, ever admitted this notion.

Conversely, one finds in Schumpeter the Austrian idea of the diffusion of beliefs by innovation/imitation, but, unlike in Hayek for example, its introduction is not intended to justify the existence of a natural tendency of the economy to converge towards a unique equilibrium. One recognizes here the complexity of the short-term as well as long-term Schumpeterian dynamics and the importance attached to the role of economic sociology (cf. for instance, contributions dedicated to this dynamics in Arena and Dangel-Hagnauer 2002).

We have now reached the limits of Schumpeter's approach. If his eclecticism allows him to provide us with a more relevant conception of economic evolution from the viewpoint of its empirical scope, it also entails a certain number of inadequacies. The one that we most want to emphasize here is the absence of a true economic explanation of the formation of collective beliefs. In Schumpeter's mind, this explanation falls essentially within the province of economic sociology, though economic sociology would be unable to provide a satisfactory answer to the economists in this context. This absence of a solution is partly the result of an unsatisfactory economic analysis in Schumpeter of the ways in which social interaction works.

\subsection{CONCLUDING REMARKS}

Our analysis has shown the great variety of approaches to the problem of beliefs in the economy within the Austrian tradition. Although this 
fact is not completely surprising for a reader familiar with the history of economic thought, its examination has the virtue of highlighting three types of solution to the problem. The approach put forward by von Mises consists in refusing any form of social or collective belief and in interpreting the processes of co-ordination through the sharing of individual beliefs. Hayek admits to the existence of a social kind of knowledge, which is both superior and different from the sum of individual types of knowledge, but denies individuals or groups of individuals the possibility of appropriating it; the 'knowledge of society' is, therefore, only a necessary analytical device. Finally, Schumpeter's analysis admits the possibility of collective beliefs and also develops the thesis according to which these beliefs affect the actions of both individuals and groups of individuals.

The Austrian tradition thus provides a considerable - though not exhaustive - overview of possible angles from which this problem could be tackled thereby also illustrating its importance. In this sense, it is striking to notice how many questions which appear new to many contemporary economists seemed natural to economists who, in their time, refused to allow their discipline to become divorced from the other social sciences.

\section{REFERENCES}

Arena, R. (1999), 'Hayek et l'équilibre économique: une autre interprétation', Revue d'Economie Politique, 109 (6).

Arena, R. (2003), 'Beliefs, knowledge and equilibrium: a different perspective on Hayek', in S. Rizzello (ed.), Cognitive Developments in Economics, London: Routledge.

Arena, R. and Dangel-Hagnauer, C. (eds) (2002), The Contribution of Joseph Schumpeter to Economics: Economic Development and Institutional Change, London: Routledge.

Arena, R. and Gloria-Palermo, S. (2001), 'Evolutionary themes in the Austrian Tradition: Menger, Wieser and Schumpeter on Institutions and Rationality', in Pierre Garrouste and Stavros Ioannides (eds), Evolution and Path Dependence in Economic Ideas: Past, Present, Aldershot: Edward Elgar.

Birner, J. (1999), 'The surprising places of cognitive psychology in the work of F.A.

Hayek', History of Economic Ideas, 7 (1-2), 43-84.

Böhm-Bawerk von, E. (1914), 'Macht Oder ökonomisches Gesetz', in Zeitschrift für Volkswirtschaft, Socialpolitik und Verwaltung, 23.

Donzelli, F. (1983), 'Schumpeter e the teoria economica neoclassica', Ricercche Economiche, XXXVII (4), 634-90. 
Fleetwood, S. (1997), 'Hayek III: The Necessity of Social Rules of Conduct', in Stephen Frowen (ed.), Hayek: the Economist and Social Philosopher-A Critical Retrospect, New York: St Martin's Press, London: Macmillian.

Garrouste, P. (1999), 'La firme "hayekienne" entre institution et organisation', Revue d'Economie Politique, 109 (6), 885-902.

Hayek, F.A. (1935), Collectivist Economic Planning: Critical Studies on the Possibilities of Socialism, London: G. Routledge \& Sons.

Hayek, F.A. (1945), 'The use of knowledge in society', American Economic Review, XXXV (5), 519-30. Reprinted in Hayek (1948).

Hayek, F.A. (1948), Individualism and Economic Order, Chicago: University of Chicago Press.

Hayek, F.A. (1952a), The Counter-Revolution of Science: Studies on the Abuse of Reason, Glencoe, Illinois: The Free Press.

Hayek, F.A. (1952b), The Sensory Order: An Inquiry into the Foundations of Theoretical Psychology, Chicago: University of Chicago Press.

Hayek, F.A. (1960), The Constitution of Liberty, Chicago: University of Chicago Press.

Hayek, F.A. (1978), 'The primacy of the abstract', in New Studies in Philosophy, Politics, Economics, and the History of Ideas, London: Routledge and Kegan Paul.

Hayek, F.A. (1988), The Fatal Conceit, London: Routledge.

Ioannides, S. (1999), 'The market, the firm, and entrepreneurial leadership: some Hayekian insights', Revue d'Economie Politique, 109 (6).

Schumpeter, J.A. ([1919] 1951), 'Zur Soziologie der Imperialismen', Archiv für Sozialwissenschaft und Sozialpolitik, 46, 1-39. Translated into English as 'The sociology of imperialisms', in J. A. Schumpeter (1951).

Schumpeter, J.A. ([1927] 1951), 'Die sozialen Klassen im ethnisch homogen Milieu', Archiv für Sozialwissenschaft und Sozialpolitik, 57, 1-67. Translated into English as 'Social classes in an ethnically homogenous environment', in J.A. Schumpeter (1951).

Schumpeter, J.A. (1934), Theory of Economic Development, Cambridge, MA: Harvard University Press.

Schumpeter, J.A. (1939), Business Cycles, 2 volumes, New York: McGraw-Hill.

Schumpeter, J.A. ([1940] 1991), 'The meaning of rationality in the social sciences', reprinted by R. Swedberg in Joseph Alois Schumpeter, The Economics and Sociology of Capitalism, Princeton University Press.

Schumpeter, J.A. (1942), Capitalism, Socialism and Democracy, New York: Harper \& Bros.

Schumpeter, J.A. (1951), Imperialism and Social Classes, P. Sweezy (ed.), New York: Augustus M. Kelley.

Vanberg, V. (1986), 'Spontaneous market order and social rules: a critical examination of F.A. Hayek's Theory of Cultural Evolution', Economics and Philosophy, 2, $75-100$.

Mises von, L. ([1924] 1981), The Theory of Money and Credit, 2nd edn, Indianapolis: Liberty Classics.

Mises von, L. ([1949] 1996), Human Action: A Treatise of Economics, 4th revised version, San Francisco: Fox \& Wilker.

Mises von, L. ([1962] 1979), The Ultimate Foundations of Economic Science, 2nd edn, Kansas City: Sheed Andrews and McMeel, 2nd. 
Wieser von, F. (1927), Social Economics, New York: Adelphi Company. Reprinted by M. Kelley Publishers in 1967. English translation of Theorie der Gesellschaftlichen Wirtschaft, 1914. 